\title{
Emergency Contraceptive Pills: Knowledge and Attitudes Of Pharmacy Personnel in Managua, Nicaragua
}

\begin{abstract}
CONTEXT: As abortion is illegal in Nicaragua, postcoital contraception is an important option for preventing pregnancy. Emergency contraceptive pills are available in Nicaraguan pharmacies over the counter, but pharmacy personnel's knowledge and attitudes about this method can affect access.

METHODS: A cross-sectional survey was conducted in Managua, Nicaragua's capital. Interviewers administered a semistructured questionnaire to 93 pharmacy employees to determine their knowledge of and attitudes toward emergency contraceptive pills. Descriptive statistics and cross-tabulations were used to examine responses of and differences between male and female employees.
\end{abstract}

RESULTS: All participants knew about emergency contraceptive pills and reported experience selling them. The majority sold them at least once a week (92\%), usually without a prescription (97\%). Of participants who were aware that emergency contraceptive pills should be taken only after sexual intercourse, $45 \%$ knew that the pills can be taken up to three days afterward; none knew that the pills are effective up to five days afterward. More than one-third of all respondents (39\%) thought the pills can induce abortion, and most overestimated contraindications and side effects. Large majorities believed the availability of emergency contraceptive pills discourages use of ongoing methods (75\%), encourages sexual risk-taking (82\%) and increases transmission of HIV and other STIs (76\%). Sixty-three participants (68\%) thought emergency contraceptive pills are necessary to reduce unwanted and unplanned pregnancy; 65\% were willing to provide them to all women in need, although only $13 \%$ would provide them to minors.

\section{CONCLUSIONS: Managuan pharmacy personnel frequently dispense emergency contraceptive pills, but need addi-} tional education to accurately counsel women about the method.

International Perspectives on Sexual and Reproductive Health, 2011,37(2):67-74, doi: 10.1363/3706711
By Nina Ehrle and Malabika Sarker

Nina Ehrle is a master's student at the Institute of Tropical Medicine and International Health, Charité-

Universitätsmedizin, Berlin, Germany. Malabika Sarker is a senior lecturer at the Institute of Public Health, University of Heidelberg, Germany.
Unintended pregnancy is a major public health problem in Nicaragua. Although the country's estimated total fertility rate dropped from 3.9 in 1998 to 2.7 in 2006-2007, ${ }^{1}$ about one in six pregnancies are still unwanted. Unintended pregnancy in Nicaragua is particularly problematic among adolescents, whose annual fertility rate of 109 births per 1,000 15-19-year-olds ${ }^{2}$ is the highest in the Americas (the World Health Organization region comprising South, Central and North America), where the average is 61 births per 1,000 adolescents. ${ }^{2}$ Approximately half of young Nicaraguan women give birth before age 20, and $45 \%$ of their births are unintended, regardless of their educational background or whether they live in urban or

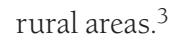

Several aspects of life in Nicaraguan society contribute to high unintended fertility. First, women are subordinate to $\mathrm{men}^{4}$ and are at risk for sexual violence ${ }^{5}$ and unexpected, undesired and unprotected intercourse. ${ }^{6}$ This makes it difficult for women to control their fertility, as does their partners' refusal to use certain contraceptive methods, like condoms. ${ }^{7}$ Second, although Nicaraguan society often encourages young men to have premarital sex, it disapproves of young women doing so. ${ }^{8}$ Thus, many young unmarried women do not seek contraceptive and reproductive health services because they fear disclosing their sexual activity. 8 In 2006, almost half of sexually active young women in Managua who were not pregnant and had no children had never used a contraceptive method. ${ }^{9}$

Third, Nicaragua bans abortion. In 2006, it became one of the few countries in the world where abortion is illegal even in cases of rape or a pregnancy threatening the woman's life. In part because of the Catholic Church's strong political influence, all proposals to legalize therapeutic abortion have been rejected. ${ }^{10}$ Since November 2007, the Nicaraguan penal code has punished abortion providers with up to eight years in jail, and women seeking abortion with a maximum of two years. ${ }^{11}$

Moreover, when abortion is illegal, women with unwanted pregnancies may turn to providers who are untrained or work in unsanitary conditions. Unsafe illegal abortion increases maternal morbidity and is a major factor in Nicaragua's maternal mortality ratio ${ }^{10}$ of 170 per 100,000 live births,${ }^{2}$ which is far higher than the regional average of 99 per $100,000 .^{2}$

To reduce unintended pregnancy and improve reproductive health in Nicaragua, women need better access to reproductive health care services, including contraceptives. ${ }^{12}$ However, existing reproductive health care centers 
TABLE 1. Percentage distribution of interviewed pharmacy personnel, by selected social and demographic characteristics, Managua, Nicaragua, 2009

\begin{tabular}{l} 
Characteristic \\
\hline Sex \\
Male \\
Female \\
\\
Age \\
$<20$ \\
$20-29$ \\
$30-39$ \\
$40-49$ \\
$\geq 50$ \\
Education or training \\
Pharmacist:university degree \\
Medical:university degree \\
Pharmacy student \\
Dispensary assistant \\
No pharmaceutical training \\
Yrs. of experience in \\
pharmacy work \\
$<5$ \\
$5-10$ \\
$>10$ \\
Religion \\
Catholic \\
Protestant \\
Other \\
No religion \\
No response \\
Total
\end{tabular}

$(\mathrm{N}=93)$

35.5

64.5

6.5
25.8
40.9
21.5
5.4

23.7
5.4
8.6
47.3
15.1


31.2
52.7
16.1

52.7
26.9
2.2
8.6
9.7

100.0

often lack qualified staff and a place to provide confidential counseling; thus, many Nicaraguan females face provider-related obstacles in obtaining such services and in receiving quality information and counseling regarding sexual health care or contraceptive methods. ${ }^{12}$

Emergency contraceptive pills are important in helping women avoid unwanted and unintended pregnancy. ${ }^{13,14}$ This hormonal contraceptive method acts by inhibiting or delaying ovulation or by preventing fertilization of an egg. ${ }^{15}$ In addition, emergency contraceptive pills do not have any contraindications. ${ }^{16}$ The method gives women-who can use it without men's cooperation or knowledge-the ability to prevent pregnancy after having unprotected intercourse (whether because of nonuse or contraceptive failure).

Although Nicaragua's Ministry of Health recommends the use of emergency contraceptive pills as a postcoital contraceptive method in the national family planning guidelines, the Catholic Church claims that they are abortifacients ${ }^{6}$ whose sale and use should be prosecuted.

According to WHO, however, the method is not an abortifacient; it is not effective once the process of implantation has begun, and it does not harm the mother or the fetus. ${ }^{17}$ Although repeated use of emergency contraceptive pills would increase side effects, such as menstrual irregularities, they pose no known health risks. ${ }^{17}$ However, emergency contraceptive pills should not be a woman's main method because they are not as effective at preventing pregnancy as modern contraceptives intended for ongoing use. ${ }^{17}$
WHO lists emergency contraceptive pills as an essential medicine that should always be available and accessible. ${ }^{18,19}$ Emergency contraceptive pills are included in Nicaragua's family planning guidelines, ${ }^{20}$ and several dedicated emergency contraception products are registered and available in the country. However, emergency contraceptive pills are not offered by Nicaragua's public health care services, which provide treatment and distribute drugs for free; they are available only in the private health care sector.

Private pharmacies are the main providers of emergency contraceptive pills, which sell for US $\$ 2-3$ with or without a prescription. Pharmacies keep long, flexible hours, including evenings and weekends, a practice that helps women obtain emergency contraception quickly. ${ }^{21}$ Pharmacies also offer an informal atmosphere in which women can obtain drugs and private health care counseling without revealing their identity ${ }^{21}$ and are preferred by girls who do not yet have children. ${ }^{9}$ According to Meuwissen et al., the majority (63\%) of sexually active 11-20-year-old females in Nicaragua who are not mothers prefer to purchase their modern contraceptives in pharmacies, whereas public health services are the most common supplier of contraceptives among females who already have children (76\%). ${ }^{9}$ Although both public health services and private pharmacies serve important functions by helping women avoid unintended pregnancy, pharmacies are especially likely to meet the needs of female adolescents, who face the highest risk of unintended pregnancy, by giving them quality reproductive health care counseling and emergency contraceptive pills.

Pharmacy personnel's knowledge and attitudes regarding emergency contraceptive pills can influence access to them, as well as their use and availability. ${ }^{14}$ Studies in other settings ${ }^{22-26}$ have revealed that lack of knowledge and negative attitudes among pharmacy and health care staff may obstruct women's access to emergency contraception. For instance, pharmacists in Jamaica and Barbados were found to lack specific knowledge about emergency contraceptive pills and overestimated their contraindications and side effects. ${ }^{22}$ Moreover, emergency contraception providers in these two countries thought that the method could encourage sexual risk-taking and lead to an increased incidence of STIs. ${ }^{22}$ Until now, little has been known about Nicaraguan pharmacy staff's awareness of emergency contraceptive pills or the way they store and sell them. The objective of this study is to identify possible barriers to Managuan women's access to these essential drugs by examining pharmacy staff's knowledge and attitudes.

\section{METHODS}

This cross-sectional descriptive survey was conducted in August and September 2009 in Nicaragua's capital, Managua. We obtained an updated list of all licensed and operating city pharmacies from the Ministry of Health. A total of 681 pharmacies were registered, but we excluded 16 from this 
study because members of the public could not use them without prior medical consultation. Using random sampling, we selected 100 pharmacies and compiled a replacement list of 20 pharmacies. We replaced nine of the originally selected pharmacies because they could not be found at the address provided or had recently closed down; pharmacies in which no staff members were willing or able to participate after three visits were not replaced.

We used a semistructured questionnaire to determine pharmacy personnel's social and demographic characteristics, the availability of emergency contraceptive pills in the selected pharmacies and pharmacy personnel's selling practices, as well as their knowledge of and attitude toward emergency contraceptive pills. The final open question gave interviewees the possibility for feedback and additional personal comments. The instrument was a modified version of a questionnaire that was used in a similar study conducted in Jamaica and Barbados. ${ }^{22}$ The questionnaire was adapted to the Nicaraguan setting, translated into Spanish, proofread by local assistants and pilot-tested in the field with pharmacy personnel who were not included in the final survey.

Data collection was conducted by two trained local assistants, who visited the sampled pharmacies up to three times during workdays and main hours of operation. Pharmacy staff were informed about the purpose of the survey and asked to recommend an employee for participation. We conducted all face-to-face interviews only after having received participants' informed verbal consent. Interviews lasted approximately 20-30 minutes. Afterward, all participants received informational material about emergency contraceptives.

Data analysis was carried out using SPSS statistical software version 13.0. We used descriptive statistics to examine the frequency of responses, and cross-tabulations to explore differences in responses between the male and female pharmacy staff we interviewed. An ethics committee of the National Autonomous University of Nicaragua reviewed this study and its instrument and granted ethical approval in July 2009.

\section{RESULTS}

A total of 93 interviews were conducted and completed. In seven pharmacies, none of the present staff members wanted to participate during any of our three visits: In four, none of the staff members were willing to take part because they had no time; in three, personnel did not wish to share their opinion because the topic was sensitive.

Most participating personnel were female (65\%, Table 1, page 68). Participants' ages ranged from 17 to 60, with a mean of 34. Most interviewees were either dispensary assistants (47\%) or pharmacists with a university degree (24\%); 15\% had no pharmaceutical training. The average length of work experience among pharmacy personnel was 7.5 years, with a range of four months to 30 years. Fifty-three percent of study participants were Catholic, and $27 \%$ were Protestant.

\begin{tabular}{|c|c|}
\hline Practice & $\begin{array}{l}\% \\
(\mathrm{~N}=93)\end{array}$ \\
\hline \multicolumn{2}{|l|}{$\geq 1$ products in stock at time of visit } \\
\hline Yes & 97.8 \\
\hline $\mathrm{No}^{*}$ & 2.2 \\
\hline \multicolumn{2}{|l|}{ Experience selling products } \\
\hline Yes & 100.0 \\
\hline No & 0.0 \\
\hline \multicolumn{2}{|l|}{ Frequency of product sales } \\
\hline Discontinued sales & 2.2 \\
\hline$\geq 1$ times a week & 92.4 \\
\hline$\geq 1$ times a month & 5.4 \\
\hline$\geq 1$ times a year & 0.0 \\
\hline$<1$ time a year & 0.0 \\
\hline \multicolumn{2}{|l|}{ Most frequent clients } \\
\hline Adolescents & 16.1 \\
\hline Adult women & 21.5 \\
\hline Women of all ages & 60.2 \\
\hline Men & 2.2 \\
\hline \multicolumn{2}{|l|}{ How products are sold in most cases } \\
\hline Patient request & 96.8 \\
\hline Patient presents prescription & 2.2 \\
\hline Pharmacy personnel recommendation & 0.0 \\
\hline With or without prescription & 1.1 \\
\hline \multicolumn{2}{|l|}{ Educational material made available } \\
\hline Yes & 35.5 \\
\hline No & 64.5 \\
\hline Total & 100.0 \\
\hline
\end{tabular}

*These two pharmacies stopped carrying emergency contraceptive pills because of a Church campaign.

\section{Stocking and Selling Practices}

Ninety-one pharmacies (98\%) had at least one emergency contraceptive product available at the time of our visit (Table 2). The two pharmacies that did not store emergency contraceptive pills reported that they had stopped selling them because of recent criticism from the Catholic Church.

All 93 participants reported having sold at least one national emergency contraceptive pill product. The vast majority (92\%) sold emergency contraceptive pills at least once a week, mainly by request to customers without a medical prescription (97\%). Given that two (2\%) of the staff worked at pharmacies that had stopped selling emergency contraceptive pills and five (5\%) sold them less than once a week, at least 29 (81\%) of the 36 staff who believed that the pills cause abortion (39\%) sold the method at least once a week (not shown). None of the interviewees generally sold the pills on their own recommendation. Only 36\% provided informational material to customers who purchased emergency contraceptive pills.

\section{Knowledge about Emergency Contraceptive Pills}

All interviewees knew about emergency contraceptive pills, and 50\% had received information about the method in the past year (Table 3, page 70). Their main source of in- 


\begin{tabular}{|c|c|}
\hline Question & $\begin{array}{l}\% \\
(\mathrm{~N}=93)\end{array}$ \\
\hline \multicolumn{2}{|c|}{ Do you know of emergency contraceptive pills? } \\
\hline Yes & 100.0 \\
\hline No & 0 \\
\hline \multicolumn{2}{|l|}{$\begin{array}{l}\text { Have you received information about } \\
\text { the method in the past year? }\end{array}$} \\
\hline Yes, more than once & 22.6 \\
\hline Yes, once & 28.0 \\
\hline No & 49.5 \\
\hline \multicolumn{2}{|l|}{ Sources of information* } \\
\hline Pharmaceutical industry & 59.6 \\
\hline Textbooks & 27.7 \\
\hline Training & 25.5 \\
\hline Pharmaceutical newspapers and brochures & 19.1 \\
\hline Internet & 12.8 \\
\hline Ministry of Health & 8.5 \\
\hline Other & 6.4 \\
\hline \multicolumn{2}{|c|}{ When must pills be taken to be clinically effective? } \\
\hline Before unprotected sexual intercourse & 10.8 \\
\hline During unprotected sexual intercourse & 7.5 \\
\hline After unprotected sexual intercourse & 78.5 \\
\hline Does not know/no response & 3.2 \\
\hline \multicolumn{2}{|c|}{$\begin{array}{l}\text { Within how many hours after unprotected sexual } \\
\text { intercourse should the pills be taken?† }\end{array}$} \\
\hline 3 & 1.4 \\
\hline 24 & 38.4 \\
\hline 48 & 15.1 \\
\hline 72 & 45.2 \\
\hline 120 & 0.0 \\
\hline \multicolumn{2}{|l|}{ Mechanism of action } \\
\hline Prevent pregnancy & 59.1 \\
\hline Induce abortion & 5.4 \\
\hline Prevent pregnancy and induce abortion & 33.3 \\
\hline Other & 2.2 \\
\hline
\end{tabular}

formation was the pharmaceutical industry (60\%); only $9 \%$ of pharmacy staff had received information from the Ministry of Health. Still, $79 \%$ of participants were aware that the pills should be taken after unprotected sexual intercourse, but fewer than half (45\%) of these knew that emergency contraceptive pills can be taken up to three days after unprotected sex. None was aware that the pills can be taken up to five days after unprotected intercourse, ${ }^{27}$ as recommended in Nicaragua's family planning guidelines. ${ }^{20}$ More than half of the participants (59\%) knew that emergency contraceptive pills only prevent pregnancy; however, $5 \%$ thought that emergency contraceptive pills could induce abortion, and 33\% believed they could both prevent pregnancy and induce abortion. Almost half of the interviewees (47\%) mistakenly believed that emergency contraceptive pills are 100\% effective, and $25 \%$ stated that they are a contraceptive method for ongoing use (not shown).

The majority of participants ( $85 \%$ ) believed that females younger than 16 or women who had used the pills in the last month (62\%) could not safely take the pills (Table 4). Only 2\% of study participants knew that breastfeeding women can use the method. Fifty-seven percent of interviewees incorrectly believed that emergency contraceptive pills could cause congenital malformations and $85 \%$ thought that they could lower women's fertility.

\section{Attitudes Regarding Emergency Contraception}

The majority of the participants stated that the availability of emergency contraceptive pills encourages sexual risktaking (82\%), increases HIV and STI transmission (76\%), discourages the use of ongoing contraceptive methods (75\%) and fosters abuse of the method or its repeated use (74\%). However, $68 \%$ maintained that emergency contraceptive pills are necessary to reduce unintended and unwanted pregnancies (Table 5).

The majority (65\%) of personnel were willing to provide the method to any woman who requested it, regardless of the circumstances; $84 \%$ were willing to provide emergency contraceptive pills to men who requested the method for their partner (Table 6, page 72). However, few (13\%) expressed willingness to sell the method to minors without parental consent. Fifty-nine percent were ready to provide emergency contraceptive pills to women in advance and 50\% said they would sell the pills to a woman more than once in a menstrual cycle (not shown). Nevertheless, only $23 \%$ reported being willing to sell emergency contraceptive pills to a woman more than five times a year. Most interviewees (69\%) wanted emergency contraceptive pills to be available only with a prescription (Table 6), and $59 \%$ felt somewhat or very uncomfortable dispensing the pills without one (not shown). Their concerns about nonprescription access were repeated use, easy access for adolescents and the possibility that a woman might use the pills without a proper medical consultation.

\section{Differences in Responses Male vs. Female Pharmacy Staff}

For the most part, the study found minimal gender differences (not shown) in participants' knowledge and perception of emergency contraceptive pills. However, much greater proportions of women than of men knew that the pills could be taken within 72 hours after unprotected intercourse ( $43 \%$ vs. $21 \%$ ), and that they work by preventing pregnancy ( $65 \%$ vs. $48 \%$ ). Nevertheless, men were more willing than women to provide emergency contraceptive pills to minors (18\% vs. $10 \%$ ).

\section{DISCUSSION}

All 93 pharmacy personnel claimed to be aware of emergency contraceptive pills and to have had experience selling emergency contraceptive products. Thus, the level of awareness and experience selling the method was greater than that of providers in other settings. ${ }^{23-25}$ The frequency of sales of emergency contraceptive pills in Managua's pharmacies substantially exceeded sales in similar pharmacy surveys in the Caribbean and Kenya. ${ }^{22,24}$

Although most of the pharmacies stored and sold emer- 
gency contraceptive pills, two had decided to stop storing or selling them because of opposition from the Catholic Church. However, at the time of this study, the Ministry of Health did not plan to remove emergency contraceptive pills from the national family planning guidelines.

Despite their awareness and frequent sales of emergency contraceptive pills, pharmacy staff lacked specific knowledge about them, and this knowledge gap could lower the quality of counseling that users receive. For example, only about one-third of all interviewees knew that emergency contraceptive pills can be taken up to 72 hours after unprotected intercourse. Managuan pharmacy personnel's knowledge about the time frame in which the method is most effective was much lower than that of pharmacists in Jamaica and Barbados 22 (45\% vs. 93\% and $70 \%) .{ }^{*}$ This lack of knowledge constitutes a barrier to emergency contraceptive pill use for women who go to a pharmacy within 72 hours after unprotected intercourse, but are erroneously informed that the pills would no longer be effective. The gender difference in knowledge about when to take emergency contraceptive pills suggests that women have more personal experience and interest regarding contraceptive issues overall.

Managuan pharmacy personnel also had less knowledge about how the pills work than did their counterparts in Jamaica ${ }^{22}$ and Kenya: ${ }^{24}$ Only 59\% knew that the pills work by preventing pregnancy. That 39\% of interviewees thought that the method could induce abortion might reflect exposure to the campaign mounted by the Catholic Church shortly before our survey. Given that inducing an abortion in Nicaragua can be punished by imprisonment, ${ }^{11}$ and that these respondents believed that emergency contraceptive pills could cause abortion, it is surprising that most of them sold the method at least once a week. Their lack of understanding about how the method works, amid a high demand for it, might explain personnel's discomfort with dispensing it without a prescription. Because pharmacy staff depend on the sale of drugs for their financial livelihood, they might feel economically pressured to sell emergency contraceptive pills.

As surveys in other settings have demonstrated, ${ }^{22,23}$ most of Managua's pharmacy staff exaggerated emergency contraceptive pills' contraindications and side effects, which could discourage use among some women. More than half of participants thought that emergency contraceptive pills could cause congenital malformations, and more than $80 \%$ believed the pills could lower women's fertility. Despite WHO's assertion that emergency contraceptive pills have no contraindications, ${ }^{16}$ more than $90 \%$ of interviewees thought that breast-feeding was contraindicated, possibly because the package leaflet of the leading brand mentions that the product is not recommended during lactation.

Information from the emergency contraceptive pill

*In both studies, only pharmacy personnel who were aware that emergency contraceptive pills should be taken after unprotected sexual intercourse were asked this question.
TABLE 4. Percentage distribution of pharmacy personnel who sell emergency contraceptive pills (ECPs), by knowledge about method contraindications and side effects

$\begin{array}{lllll}\text { Measure } & \begin{array}{l}\text { Yes } \\ \%\end{array} & \begin{array}{l}\text { No } \\ \%\end{array} & \begin{array}{l}\text { Does not } \\ \text { know/no } \\ \text { response }\end{array} & (\mathrm{N}=93) \\ & & & \end{array}$

\section{Consider ECPs safe despite these}

potential contraindications

Female smokers $>35 \quad 57.0$

$\begin{array}{llll}\text { Used method within last month } & 35.5 & 62.4 & 2.2\end{array}$

$\begin{array}{llll}\text { Breast-feeding } & 2.2 & 97.8 & 0.0\end{array}$

$\begin{array}{llll}\text { Pregnant or possibly pregnant } \quad 1.1 & 97.8 & 1.1\end{array}$

100.0

100.0

100.0

100.0

100.0

Possible side effects

Nausea and vomiting

$84.9 \quad 11.8 \quad 3.2$

Altered menstrual bleeding

Congenital malformations

$\begin{array}{lll}97.8 & 1.1 & 1.1\end{array}$

$\begin{array}{lll}57.0 & 25.8 & 17.2\end{array}$

Lowered fertility

$84.9 \quad 9.7 \quad 5.4$

100.0

100.0

100.0

100.0

manufacturer stating that the product is not recommended before menarche might also have influenced pharmacy staff, $85 \%$ of whom said that the pills were contraindicated for adolescents younger than 16; unwillingness among $82 \%$ to sell the method to minors without parental consent indicates that adolescents could face problems obtaining emergency contraceptive pills from pharmacies. Thus, despite their need for postcoital contraceptives, adolescent girls face access problems both from public providers, as an earlier study in Managua found, ${ }^{28}$ and from private providers, such as pharmacies. Research from South Africa, ${ }^{26}$ Jamaica and Barbados ${ }^{22}$ suggests that substantial proportions of health care providers in those countries also deny adolescents access to emergency contraceptive pills.

Pharmacies are important providers of contraceptives for teenagers, and one in six pharmacies sold emergency contraceptive pills mainly to adolescents. This methodwhich could help reduce the high rate of unintended adolescent pregnancy in Nicaragua-could allow teenagers to TABLE 5. Percentage distribution of pharmacy personnel, by agreement with
statements about availability and necessity of emergency contraceptive pills

Statement

Totally Some- Some- Totally Doesn't Total

agree what what disagree know/no $(\mathrm{N}=93)$ agree disagree response

The availability of ECPs

encourages sexual risk-taking.

69.9

11.8

2.2

12.9

3.2

100.0

The availability of ECPs

discourages use of ongoing

contraceptive methods.

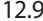

2

22.6

0.0

100.0

Wide availability of ECPs

does not lead to abuse or

repeated use.

11.8

9.7

10.8

63.4

4.3

100.0

The availability of ECPs

increases the transmission of

HIV and other sexually transmitted

infections.

72.0

4.3

5.4

17.2

1.1

100.0

ECPs are a necessary method

to reduce unwanted and

unplanned pregnancies. 
TABLE 6. Willingness of pharmacy staff to provide emergency contraceptive pills to certain clients and concerns regarding availability of the method over the counter

Question

Yes No Doesn't Tota

know/no $(\mathrm{N}=93)$

response

\section{Would you provide ECPs to:}

Rape victims

Women whose partner's condom broke or slipped off

Women who incorrectly used a contraceptive method

Women who did not use any contraceptive method

Minors without parental consent

Sex workers

Men who request ECPs for their partner

Any woman who requests ECPs, regardless of circumstances

\section{Should ECPs be available only with a prescription?}

\section{Are you concerned about selling ECPs}

\section{over the counter because:*}

Women lose the benefits of a consultation with a doctor.

Some women use the method repeatedly.

Adolescents have easy access to emergency

contraceptive pills and abuse them.

Women need medical supervision to take the pills.

*Only the 64 participants who had stated that emergency contraceptive pills should be available only with a prescription were asked this question.

avoid such pregnancies without the knowledge of parents or other family members who might disapprove of premarital sexual activity. Nevertheless, pharmacy personnel did not support teenagers' use of emergency contraceptive pills and most disapproved of the method's over-thecounter availability, lest adolescents abuse it.

That pharmacy staff were most willing to sell emergency contraceptive pills to men who requested the method for their partner might be a reflection of Nicaragua's gender issues and men's dominant role within society. It also might reflect pharmacy personnel's support and appreciation for men's collaboration in contraceptive issues. Pharmacists in Jamaica and Barbados were less willing to sell the method to men (44\% and $50 \%$ vs. $84 \%$ ). ${ }^{22}$

Overall, the majority of study participants expressed negative attitudes toward emergency contraceptive pills. They were particularly concerned that the pills' availability might encourage sexual risk-taking-including lack of condom use-and increase the transmission of HIV and other STIs.

This study has several limitations. The results cannot be generalized to any other urban or rural area in Nicaragua, since Managua's level of health care services and medical knowledge is the highest in the country. Also, knowledge and certain attitudes among pharmacy personnel who declined to participate in the study may differ from those of the respondents. Finally, interviewees might have provided the answers they thought the researchers wanted to hear instead of those that reflected their performance and behavior in daily practice.

\section{CONCLUSION}

Managuan pharmacies have frequent contact with Nicaraguan women in need of emergency contraception and play an important role as providers of emergency con- traceptive pills and reproductive health care counselors. They also would be an ideal source for educational material, which they currently do not provide. Consequently, pharmacies are uniquely positioned to help tackle such public health problems as unintended pregnancy and the high adolescent fertility rate.

However, educational campaigns are needed to ensure a high level of knowledge about emergency contraceptive pills among pharmacy staff, so that women, particularly adolescents, who need the method can receive quality counseling and access to it. Pharmacy personnel should be informed about and involved in the planning and implementation of national recommendations and strategies regarding sexual and reproductive health.

Finally, educational campaigns about sexual health and gender issues should target teenagers and include information about contraceptive options, HIV and other STIs and the importance of condom use.

\section{REFERENCES}

1. National Institute for Development Information (INIDE) and Ministry of Health Nicaragua, Nicaraguan Demographic and Health Survey 2006-2007, Preliminary Report, Managua, Nicaragua, September 2008, <http://www.inide.gob.ni/bibliovirtual/Publicacion09/EndesaV. ingles.pdf>, accessed May 5, 2011.

2. World Health Organization (WHO), World Health Statistics 2009 , Geneva: WHO, 2009.

3. Blandón L et al., Early childbearing in Nicaragua: a continuing challenge, In Brief, New York: Guttmacher Institute, 2006.

4. European Commission, Country Strategy Paper Nicaragua 20072013, European Union: European Commission, 2007, <http://www. eeas.europa.eu/nicaragua/csp/07_13_en.pdf $>$, accessed Jan. 21, 2011.

5. Amnesty International, The Impact of the Complete Ban of Abortion in Nicaragua: Briefing to the United Nations Committee Against Torture, London: Amnesty International, 2009, <http://www.amnesty.org/ en/library/asset/AMR43/005/2009/en/3394566e-4045-43f7-902cb9f50181fcf5/amr430052009en.pdf>, accessed Jan. 21, 2011.

6. Faúndes A et al., Emergency contraception under attack in Latin America: response of the medical establishment and civil society, Reproductive Health Matters, 2007, 15(29):130-138.

7. Berglund $S$ et al., The background of adolescent pregnancies in Nicaragua: a qualitative approach, Social Science \& Medicine, 1997, 44(1):1-12.

8. Rani M, Figueroa ME and Ainsle R, The psychological context of young adult sexual behavior in Nicaragua: looking through the gender lens, International Family Planning Perspectives, 2003, 29(4):174181 .

9. Meuwissen LE et al., Uncovering and responding to needs for sexual and reproductive health care among poor urban female adolescents in Nicaragua, Tropical Medicine and International Health, 2006, 11(12):1858-1867.

10. Getgen JE, Reproductive injustice: an analysis of Nicaragua's complete abortion ban, Cornell International Law Journal, 2008, 41(1):143175.

11. Penal Code of Nicaragua, Arts. 143-145, 2007.

12. Meuwissen LE, Gorter AC and Knottnerus AJ, Impact of accessible sexual and reproductive health care on poor and underserved adolescents in Managua, Nicaragua: a quasi-experimental intervention study, Journal of Adolescent Health, 2006, 38(1):56.el-56.e9.

13. Trussell J and Raymond E, Emergency Contraception: A Last Chance to Prevent Unintended Pregnancy, Princeton, NJ: Office of Population Research, Princeton University, 2010, <http://ec.princeton.edu/questions/ec-review.pdf>, accessed Jan. 21, 2011. 
14. Schiappacasse V and Diaz S, Access to emergency contraception, International Journal of Gynaecology and Obstetrics, 2006, 94(3):301309.

15. Glasier A, Emergency postcoital contraception, New England Journal of Medicine, 1997, 337(15):1058-1064.

16. WHO, Medical Eligibility Criteria for Contraceptive Use, third ed., Geneva: WHO, 2004.

17. WHO, Emergency contraception, Fact Sheet No. 244, Geneva: WHO, <http://www.who.int/mediacentre/factsheets/fs244/en>, accessed Jan. 21, 2011.

18. WHO, WHO Model List of Essential Medicines, $15^{\text {th }}$ List, Geneva: WHO, 2007.

19. WHO, United Nations Population Fund and PATH, Essential Medicines for Reproductive Health: Guiding Principles for Their Inclusion on National Medicines List, Geneva: WHO, 2006.

20. Ministerio de Salud Nicaragua, Norma y Protocolo de Planificación Familiar, Managua: Ministerio de Salud Nicaragua, 2008.

21. Boggess JE, How can pharmacies improve access to emergency contraception? Perspectives on Sexual and Reproductive Health, 2002, 34(3):162-165.

22. Yam EA et al., Jamaican and Barbadian health care providers' knowledge, attitudes and practices regarding emergency contraceptive pills, International Family Planning Perspectives, 2007, 33(4):160-167.

23. Langer A et al., Emergency contraception in Mexico City: what do health care providers and potential users know and think about it? Contraception, 1999, 60(4):233-241.

24. Muia E et al., Emergency contraception in Nairobi, Kenya: knowledge, attitudes and practices among policymakers, family planning providers and clients, and university students, Contraception, 1999, 60(4):223-232

25. Tripathi R, Rathore AM and Sachdeva J, Emergency contraception: knowledge, attitude, and practices among health care providers in North India, Journal of Obstetrics and Gynaecological Research, 2003, 29(3):142-146.

26. Blanchard K, Harrison T and Sello M, Pharmacists' knowledge and perceptions of emergency contraceptive pills in Soweto and the Johannesburg Central Business District, South Africa, International Family Planning Perspectives, 2005, 31(4):172-178.

27. Rodrigues I, Grou F and Joly J, Effectiveness of emergency contraceptive pills between 72 and 120 hours after unprotected sexual intercourse, American Journal of Obstetrics and Gynecology, 2002, 186(1): $167-168$

28. Meuwissen LE et al., Does a competitive voucher program for adolescents improve the quality of reproductive health care? A simulated patient study in Nicaragua, BMC Public Health, 2006, <http://www. biomedcentral.com/content/pdf/1471-2458-6-204.pdf>, accessed May 12, 2011.

\section{RESUMEN}

Contexto: Dado que el aborto es ilegal en Nicaragua, la anticoncepción postcoital es una opción importante para prevenir el embarazo no planeado. El método de anticoncepción de emergencia está disponible sin receta en las farmacias nicaragüenses, pero los conocimientos y actitudes del personal de las farmacias respecto a este método pueden afectar el acceso.

Métodos: Se condujo una encuesta transversal en Managua, la capital de Nicaragua. Los entrevistadores aplicaron un cuestionario semi-estructurado a 93 empleados de farmacias para determinar su nivel de conocimientos y actitudes en relación con las píldoras de anticoncepción de emergencia. Se utilizaron estadisticas descriptivas y tabulaciones cruzadas para examinar las respuestas y las diferencias entre empleados y empleadas.
Resultados: Todos los participantes conocían las pildoras de anticoncepción de emergencia y confirmaron tener experiencia en su venta. La gran mayoría las vendía al menos una vez por semana (92\%), usualmente sin receta (97\% de ellos). De los participantes que estaban conscientes de que dichas píldoras deben tomarse después de la relación sexual, el 45\% sabía que las píldoras pueden tomarse hasta tres días después; ningún participante sabia que las puede tomar hasta cinco dias después. Más de una tercera parte del total de personas entrevistadas (39\%) pensaba que las píldoras pueden inducir el aborto; y la mayoría sobreestimaba los efectos secundarios y las contraindicaciones a su uso. Grandes mayorías creían que la disponibilidad de la anticoncepción de emergencia alienta las conductas sexuales de riesgo (82\%), aumenta la transmisión del VIH y otras ITS (76\%) y desalienta el uso de métodos anticonceptivos regulares $(75 \%)$. Sesenta y tres participantes (68\%) pensaban que la anticoncepción de emergencia es necesaria para reducir los embarazos no deseados y no planeados; $65 \%$ estaba de acuerdo en proporcionarlas a todas las mujeres que las necesitaran, aunque solamente 13\% las proporcionaría a menores de edad.

Conclusiones: El personal de farmacias en Managua frecuentemente expende píldoras de anticoncepción de emergencia, pero necesita capacitación adicional para que aconsejen con exactitud a las mujeres acerca del método.

\section{RÉSUMÉ}

Contexte: Étant donné que l'avortement est illégal au Nicaragua, la contraception post-coïtale représente une option importante de prévention de la grossesse. Les pilules contraceptives d'urgence sont disponibles en vente libre dans les pharmacies du Nicaragua. La connaissance de la méthode par le personnel des pharmacies et ses attitudes à son égard peuvent cependant affecter l'accès.

Méthodes: Une enquête transversale a été menée à Managua, capitale du Nicaragua. Les intervieweurs ont présenté un questionnaire semi-structuré à 93 employés de pharmacie afin de déterminer leur connaissance des pilules contraceptives d'urgence et leurs attitudes à son égard. Les réponses et les différences entre les employés de sexe masculin et féminin ont été examinées par statistiques descriptives et tableaux à double entrée.

Résultats: Tous les participants connaissaient des pilules contraceptives d'urgence et ont déclaré les avoir déjà vendu. La majorité les vendait au moins une fois par semaine (92\%), généralement sans ordonnance (97\%). Des participants qui savaient que les pilules contraceptives d'urgence ne doivent être prises qu'après que des rapports sexuels ont eu lieu, 45\% savaient qu'elles peuvent être prises jusqu'à trois jours après l'acte; aucun ne savait qu'elles sont efficaces jusqu'à cinq jours après l'acte. Plus du tiers de l'ensemble des répondants (39\%) pensaient que les pilules peuvent provoquer un avortement et la plupart en surestimaient les contre-indications et les effets secondaires. De grandes majorités estimaient que la disponibilité des pilules contraceptives d'urgence défavorise la pratique de méthodes continues (75\%), favorise la prise de risques sexuels (82\%) et accroît la transmission du VIH et d'autres IST 
(76\%). Soixante-trois participants (68\%) estimaient que les pilules contraceptives d'urgence sont nécessaires à la réduction des grossesses non désirées et non planifiées; 65\% étaient disposés à les procurer à toutes les femmes qui en ont besoin, mais 13\% seulement les donneraient à des mineures.

Conclusions: Le personnel des pharmacies de Managua délivre fréquemment les pilules contraceptives d'urgence mais doit être informé davantage pour conseiller correctement les femmes sur la méthode.

\section{Acknowledgments}

The authors thank Sandra Garcia and Eileen Yam of Population Council, Mexico, for sharing their questionnaire, and Armando Ulloa, Roger Gonzales and Yadira Medrano at the National Autonomous University of Nicaragua for their support in the field. We also thank Luis Jaime Arguello and Carlos Guevara, Universidad Americana Managua; Luis Carlos Berrocal Almanza and Frank P. Schelp, professor emeritus at the Institute of Tropical Medicine and International Health, Charité-Universitätsmedizin Berlin, Germany.

Author contact:nina.ehrle@gmail.com 